\title{
HUBUNGAN ANTARA GAYA HIDUP DAN KONSEP DIRI \\ DENGAN INTERAKSI SOSIAL PADA REMAJA
}

\author{
Minggus Salvinus Masela \\ alvinmasela@gmail.com
}

\begin{abstract}
ABSTRAK: Perkembangan interaksi sosial yang baik dengan semua orang berkaitan dengan gaya hidup dan konsep diri. Penelitian ini bertujuan untuk mengetahui keterkaitan antara gaya hidup dan konsep diri dengan interaksi sosial. Subyek penelitian ini adalah 95 siswa IPA-IPS kelas I dan II SMA Taman Harapan Malang. Data penelitian ini dikumpulkan dengan menggunakan skala gaya hidup, skala konsep diri dan skala interaksi sosial yang disusun oleh peneliti. Hipotesis dianalisa dengan program SPSS 21. Hasilnya menunjukkan bahwa gaya hidup dan konsep diri berkorelasi secara signifikan dengan interaksi sosial di mana nilai $\mathrm{F}$ sebesar 17, 695 pada nilai p sebesar 0,000 ( $\mathrm{p}<0,01)$. Koefisien determinasi sebesar 0,278, sehingga hal ini berarti kedua variabel bebas (gaya hidup dan konsep diri) memberikan sumbangan efektif secara bersama-sama sebesar 27, 8\% kepada variabel terikat (interaksi sosial). Prosentase determinasi menunjukkan bahwa konsep diri lebih memberikan sumbangan efektif $(0,251 \%)$ daripada gaya hidup sebesar $(0,17 \%)$.
\end{abstract}

Kata Kunci: Interaksi Sosial, Gaya Hidup, Konsep Diri.

ABSTRACT: The development of good social interaction with all the people related to lifestyle and self-concept. This study aims to determine the relationship between lifestyle and self-concept and social interaction. The subjects of this study were 95 students IPA-IPS class I and II SMA Garden of Hope Malang. The research data were collected by using a scale lifestyle, self-concept scale and social interaction scale developed by the researchers. Hypothesis 21 analyzed with SPSS results show that the self-concept lifestyle and significantly correlated with social interaction in which the $F$ value of 17,695 at $p$ value of 0.000 ( $\mathrm{p}<0.01)$. The coefficient of determination equal to 0.278 , so this means that the two independent variables (lifestyle and self-concept) contribute effectively together by $27,8 \%$ to the dependent variable (social interaction). Percentage indicates that the concept of selfdetermination is more effective contribution by $(0.251 \%)$ to social interaction and lifestyle effective contribution by $(0,17 \%)$.

Keywords: Life Style, Self Concept, Social Interaction.

\section{PENDAHULUAN}

Winkel (1996) menyatakan bahwa

pendidikan merupakan hal yang penting

dalam kehidupan manusia dan ini menjadi tanggung jawab tidak hanya guru di sekolah namun juga keluarga dan

masyarakat luas. Pendidikan dapat diartikan pula sebagai bantuan yang 
diberikan oleh orang dewasa kepada yang belum dewasa agar dia mencapai kedewasaan (Setiawati, 2010). Untuk mencapai potensi-potensi tersebut, manusia sebagai makhluk sosial tidak dapat bekerja sendiri, akan tetapi membutuhkan hubungan atau interaksi sosial dengan orang lain, bukan hanya untuk mempertahankan hidupnya, melainkan juga untuk melakukan kegiatan lainnya

Bagi remaja, kebutuhan untuk berinteraksi dengan orang lain diluar lingkungan keluarganya ternyata sangat besar, terutama kebutuhan berinteraksi dengan teman-teman sebayanya. Dari hasil penelitian Larson dkk (dalam Sears, 1991) menemukan fakta, bahwa 74, 1\% waktu remaja dihabiskan bersama orang lain diluar lingkungan keluarganya. Berdasar hasil penelitian ini dapat dikatakan bahwa interaksi sosial atau menjalin hubungan dengan orang lain merupakan kebutuhan yang penting dan mendasar bagi remaja mengingat sebagian besar waktu mereka dihabiskan bersama orang-orang diluar lingkungan keluarganya (Nirwana, 2013). Ketika seseorang untuk pertama kalinya bertemu dengan orang lain yang baru saja dikenalnya, maka mereka tidak dapat diharapkan langsung menjadi akrab atau bahkan bermusuhan. Menurut Knapp (1984) interaksi sosial dapat menyebabkan seseorang menjadi dekat dan merasakan kebersamaan, atau sebaliknya dapat menyebabkan seseorang menjadi jauh dari suatu hubungan interpersonal.

$$
\text { Miraningsih (2013) meng- }
$$
gambarkan fenomena yang terjadi di Madrasah Aliyah Negeri (MAN) Purworejo menunjukkan adanya perilaku seksual yang negatif. Menurut hasil analisis identifikasi kebutuhan dan masalah siswa (IKMS), terdapat 11 (Sebelas) siswa dari 288 siswa kelas XI secara keseluruhan yang mengalami masalah terkait dengan pelanggaran norma agama. Berdasarkan informasi dari konselor sekolah, pelanggaran yang dimaksud adalah siswa 
pernah melakukan hubungan intim dengan pasangannya. Rasa ingin tahu yang besar dalam diri remaja terkait dengan reproduksi sehat, mendorong remaja untuk mencari informasi kepada teman sebaya, orang tua, atau pun dengan lingkungan sekitarnya. Remaja banyak menghabiskan waktu luang dengan teman sebayanya. Dalam hal ini, teman sebaya seringkali berperan sebagai tempat bertukar pengalaman, termasuk dalam hal kesehatan reproduksi. Permasalahan diatas menjelaskan bahwa rasa ingin tau akan suatu informasi yang berguna, telah berakibat pada permasalahan perilaku seks yang terjadi lewat interaksi sosial diantara siswa Madrasah Aliyah Negeri (MAN) Purworejo.

$$
\text { Revida (2006), juga }
$$
menggambarkan fenomena lainya tentang hubungan antar etnik-china dan penduduk pribumi yang menunjukkan kurangnya interaksi sosial cenderung mengarah ke situasi konflik. Peristiwa 10 Desember
1966 tentang pembubaran PKI di Konsulat RRC di Medan, yang berbuntut matinya seorang pemudah Aceh, sehingga menimbulkan amarah penduduk pribumi dengan membunuh orang China lebih dari 200 orang. Demonstrasi mahasiswa USU Medan pada tahun 1980 Stereotip tersebut. Sifat tertutup seperti ini tentu menghambat komunikasi yang sangat diperlukan dalam pembauran, sebab komunikasi merupakan syarat mutlak untuk terjadinya interaksi sosial yang harmonis, yang pada gilirannya dapat menumbuhkan rasa saling menghormati antar orang China dan pribumi. Permasalahan ini secara tidak langsung memberikan dampak yang kurang baik bagi remaja yang menyaksikan peristiwa tersebut karena akan membatasi interaksi sosial diantara kedua etnis.

Menurut Maryati dan Suryawati (2003) interaksi sosial adalah kontak atau hubungan timbal balik atau interstimulasi dan respon antara individu, antar kelompok atau antar individu dan kelompok. Siswa 
diharapkan memiliki interaksi sosial baik, akan menciptakan hubungan harmonis yang dapat dilihat dengan adanya kerja sama dalam menyelesaikan permasalahan, saling menghargai dan saling menghormati. Apabila para siswa memiliki interaksi sosial yang kurang baik akan mengakibatkan kesulitan dalam menjalin hubungan baik dengan semua teman-teman yang ditandai dengan adanya rasa kebencian, dan kurangnya kerjasama diantara siswa. Bentuk-bentuk interaksi sosial yang kurang baik dapat kita lihat dimana siswa saling membenci, saling menjatuhkan, dan terbentuknya kelompok teman sebaya dimana masing-masing kelompok saling menyerang atau saling menjatuhkan sehingga akan menciptakan hubungan yang kurang harmonis diantara siswa. Interaksi sosial yang kurang baik di lingkungan sekolah juga akan menciptakan suasana belajar yang kurang nyaman atau kondusif dan akhirnya akan mempengaruhi hasil belajar yang dicapainya.
Gim (2011), tingkah laku individu yang dimanifestasikan, pada hakekatnya bersumber dari potensi yang menetap dalam diri individu itu sendiri. Semua tingkah laku itu pada dasarnya mencerminkan individu di dalam kelompok. Tingkah laku ini cocok atau sesuai dengan konsep masyarakat yang dituntutkan pada masing - masing individu tersebut. Dengan demikian sebagian besar dari tingkah laku manusia itu selalu berkorelasi pula dengan situasi sosial dan peranan sosial.

Gim (2011), dalam datanya berpendapat bahwa dalam meningkatkan interaksi sosial, perlu adanya kekuatan dalam hubungan sosial. Kekuatan hubungan yang intens mengacu pada tingkat seberapa kuat, yaitu individu memiliki lebih banyak kesempatan untuk membuktikan kompetensi, kemampuan, keterampilan sosial, dan kepribadian yang baik, bahkan jika hubungan yang tidak berlangsung lama. Dan sebaliknya jika 
hubungan menjadi lemah, individu kurang memiliki kesempatan yang cukup untuk membuktikan keunggulan mereka. Dalam berinteraksi dengan orang lain secara intensif dalam berbagai konteks sosial, individu menjadi mandiri, memiliki dan mengembangkan ikatan sosial yang kuat serta mendalam. Perubahan-perubahan yang terjadi ini tergantung pada orang atau kelompok yang memberikan pengaruh, seberapa besar ia dapat mempengaruhi orang lain. Perubahan juga tergantung dari bagaimana orang yang diberikan pengaruh itu memberikan reaksi atau tanggapan.

Kondisi yang menarik dalam berinteraksi tentu tidak lepas dari kondisi fisik lingkungan tersebut, terutama kondisi siswa-i di SMA Taman Harapan Malang yang masih berkelompok atau memiliki gap sendiri-sendiri dalam berinteraksi satu dengan yang lainnya. Siswa-i diharapkan dapat menyesuaikan dengan lingkungan dan kondisi tempat yang mendukung dalam berinteraksi. Tempat dan individu yang sesuai akan menjamin terciptanya hubungan yang baik dalam interaksi sosial, karena dengan memperhatikan lingkungan dan gaya hidup yang ada akan menimbulkan interaksi yang lebih baik.

Interaksi sosial telah dipengaruhi oleh berbagai faktor yaitu motivasi, kelas sosial, usia, jenis kelamin, informasi sosial/ media sosial, identitas diri, ethnic, harga diri, situs jejaring sosial facebook, kebudayaan, konsep diri, gaya hidup, percaya diri, status sosial ekonomi orang tua. Dari berbagai faktor diatas, peneliti telah mempertimbangkan dan memutuskan untuk memilih faktor gaya hidup dan konsep diri sebagai landasan teori dalam mempengaruhi permasalahan dari interaksi sosial.

Sudjiwanati (2008), gaya hidup merupakan salah satu faktor yang mempengaruhi tingkah laku individu, termasuk pula perilaku dalam berinteraksi. Individu yang memiliki gaya hidup rumahan, dan sebaliknya. Individu yang 
memiliki gaya hidup hura-hura lebih suka berhubungan dengan individu yang sama. Gaya hidup seseorang dapat menyebabkan timbulnya selektifitas dan distorsi pada mental, gaya hidup berpengaruh terhadap tempat-tempat yang diketahui dan didatangi, gaya hidup antara individu satu dengan individu lain berbeda. Gaya hidup seseorang dipengaruhi oleh latar belakang lingkungan orang tersebut. Hal ini sangat erat kaitannya dengan interaksi sosial tiap individu dan menjadi penting karena dalam sebuah komunitas atau lingkungan hal tersebut menjadi tempat untuk membentuk suatu kepribadian seseorang, dan mereka harus menyesuaikan diri dengan lingkungan mereka tinggal supaya tidak dikucilkan atau dianggap tidak bisa bersosialisasi dengan lingkungan sosial meskipun proses tersebut membutuhkan waktu yang lama.

Susianto dalan Sudjiwanati, (2008) mengatakan bahwa konsep gaya hidup ini menjadi sangat penting karena gaya hidup berguna untuk memberi pemahaman yang lebih rinci terhadap gradasi dari masyarakat perkotaan yang digambarkan dengan struktur seperti kelas sosial, usia, jenis kelamin dan etnik. Dengan konsep gaya hidup akan memperoleh gambaran yang lebih bernuansa tentang mereka.

$$
\text { Menurut Widiastutik (1999), }
$$

mengatakan bahwa gaya hidup secara luas diartikan sebagai sebuah mode kehidupan yang diidentifikasikan dengan bagaimana orang menghabiskan waktu mereka, apa yang mereka anggap penting dengan lingkungan mereka dan apa yang mereka pikir tentang diri mereka dan lingkungan mereka. Untuk bisa mengikuti gaya hidup yang baru, diperlukan dukungan kemampuan ekonomi yang tinggi. Kebutuhan ini sangat terasa. Tawaran gaya hidup yang ditawarkan melalui kaca-kaca ruang pameran tokoh atau distributor benda-benda yang digandrungi telah memacu banyak orang untuk bisa memilikinya. 
Selain gaya hidup, faktor lain yang diduga dapat mempengaruhi intraksi sosial adalah konsep diri. Oleh karena itu salah satu mekanisme yang perlu dimiliki adalah konsep diri yang positif. Konsep diri yang dimiliki oleh siswa akan mempengaruhi perilakunya dalam hubungan sosial dengan individu lain. Konsep diri tinggi atau positif akan berpengaruh pada perilaku positif, sebaliknya konsep diri rendah atau negatif, akan membawah pengaruh yang kurang baik bagi perilaku siswa. Konsep diri seseorang dinyatakan melalui sikap dirinya yang merupakan aktualisasi orang tersebut. Manusia sebagai organism yang memiliki dorongan untuk berkembang yang pada akhirnya menyebabkan ia sadar akan keberadaan dirinya.Perkembangan yang berlangsung tersebut kemudian membantu pembentukan konsep diri individu yang bersangkutan (Nirwana, 2013).

Konsep diri belum ada sejak lahir, tapi berkembang secara bertahap dan juga dipelajari melalui kontak sosial dan pengalaman hubungan dengan orang lain dan objek di sekitarnya. Konsep diri berkembang sejak bayi dapat mengenal, membedakan orang lain, serta mulai membedakan dirinya dengan lingkungannya (Depkes RI, 1995). Menurut Potter \& Perry (1997/2005) konsep diri merupakan pengetahuan individu mengenai diri dan bertujuan untuk memberikan kerangka acuan yang mempengaruhi manajemen diri terhadap situasi dan hubungan dengan orang lain.

Sudjiwanati (2008), konsep diri merupakan produk sosial dan terbentuk dalam proses interaksi sosial yang selanjutnya berkembang dan berubah melalui interaksi sosial juga kosep diri tumbuh dari hubungan antara anak dengan orang lain terutama orang-orang yang berarti dalam hidup (significant others) dalam hidup anak, seperti teman, guru, dan orang tua, guru perlu memperhatikan penyesuaian diri anak, karena pola perilaku 
dan sikap yang tertanam pada anak interaksi antara individu dengan cenderung menetap dan akan lingkungan. Pandangan yang dimiliki meninggalkan ciri pada konsep diri tentang siapa diri kita tidaklah bersifat mereka.

Konsep diri adalah variabel yang akan ikut menentukan bagaimana individu manusia.

menerima, merasakan dan merespon diri dan lingkungannya. Bila individu

\section{Interaksi Sosial}

menerima dirinya kurang baik, maka

Sebagai makhluk individu dan individu akan menganggap remeh dan membayangkan kegagalan usahanya, sedangkan bila individu menilai dirinya positif maka individu akan bersifat optimis dan berusaha untuk mengatasi kesulitan (Fuhrmann, 1990).

Miraningsih (2013), konsep diri yang dimiliki remaja akan mempengaruhi perilakunya dalam hubungan sosial dengan individu lain. Konsep diri tinggi atau positif akan berpengaruh pada perilaku positif. Sebaliknya konsep diri rendah atau negatif akan membawa pengaruh yang kurang baik bagi perilaku individu. Perkembangan konsep diri dimulai dengan 
memenuhi kebutuhan hidup. Melalui hubungan itu individu ingin menyampaikan maksud, tujuan dan keinginan masing-masing. Untuk mencapai keinginan tersebut biasanya diwujudkan dengan tindakan melalui hubungan timbal balik, hubungan inilah yang disebut dengan interaksi (Basrowi, 2005).

Interaksi sosial menurut pendapat Gillin (dalam Soerjono Soekanto, 2006) merupakan hubungan sosial yang dinamis yang menyangkut hubungan orang-orang perorangan, antara kelompok-kelompok manusia, maupun antara orang perorangan dengan kelompok manusia. Apabila dua orang bertemu, interaksi sosial dimulai pada saat itu. Mereka saling menegur, berjabat tangan, saling berbicara atau bahkan mungkin berkelahi. Pertemuan itu merupakan suatu interraksi sosial.

Menurut Basrowi dalam pengantar sosiologi (2005), “interaksi sosial adalah hubungan dinamis yang mempertemukan orang dengan orang, kelompok dengan kelompok maupun orang dengan kelompok manusia. Bentuknya tidak hanya bersifat kerja sama, tetapi bisa juga berbentuk tindakan persaingan, pertikaian dan sejenisnya.

Interaksi terjadi apabila seorang individu melakukan tindakan, sehingga menimbulkan reaksi dari individu-individu yang lain, karena itu interaksi terjadi dalam suatu kehidupan sosial dan dengan tepat menggambarkan kelangsungan hubungan timbal-balik antara dua atau lebih manusia. Yang dapat disebutkan bahwa interaksi sosial adalah suatu hubungan antara dua atau lebih individu manusia, dimana kelakuan individu yang satu mempengaruhi, mengubah atau memperbaiki kelakuan individu yang lain atau sebaliknya (Gerungan, 2004).

Interaksi sosial adalah suatu pertukaran antar pribadi yang masingmasing orang menunjukkan perilakunya satu sam lain dalam kehadiran mereka yang masing-masing perilaku 
mempengaruhi satu sama lain (dalam Ali dan Asrori, 2004). Interaksi sosial adalah proses timbal balik antara individu satu dengan individu lain dan mereka saling mempengaruhi satu sama lain (Chaplin J.P, 2006). Contoh: Andika yang memiliki bakat gitaris lebih memilih untuk berinteraksi dan terlibat dengan kelompok yang memiliki musik band ternama di sekolahnya, karena dirasa akan membantu dirinya untuk lebih dikenal oleh banyak orang; oleh karenanya, sikap dan perilakunya yang berkaitan dengan musik selalu diperlihatkan menarik perhatian group band tersebut sehingga bisa diterima untuk bergabung.

Pendapat Young (2000) tentang interaksi sosial merupakan kontak timbal balik antara dua orang atau lebih. Menurut Psycologi tingkah laku (Behaviouristis Psycologi, 2000). Bahwa interaksi sosial adalah berisikan saling perangsangan dan perealisasian antara kedua belah pihak individu.
Penjelasan diatas dapat disimpulkan bahwa interaksi sosial mengandung hubungan timbal balik antara dua orang atau lebih dan masing-masing orang terlibat di dalamnya memainkan peran secara aktif.

Peneliti menggunakan percampuran antara ciri-ciri (Santosa, 2004) dan syarat (Muftuh dan Ruyadi (1995) sebagai acuan untuk membuat alat ukur interaksi sosial yait: (1) Kontak sosial dapat berupa suatu kontak primer maupun sekunder. Kontak primer terjadi apabila yang mengadakan hubungan langsung bertemu dan berhadapan muka, berjabat tangan, saling tersenyum dan seterusnya. Sementara itu kontak yang bersifat sekunderpun dapat bersifat langsung bila perantaranya melalui surat, telepon dan sejenisnya.

Komunikasi adalah proses dimana seorang individu (komunikator) mengoperkan perangsang untuk mengubah tingkah laku individu yang lain (komunikan). (Hovland dan Abdurahman, 2001). Suatu komunikasi 
terjadi, bila seseorang memberikan tafsiran pada perilaku orang lain yang terwujut pembicaraan, gerak-gerak jasmaniah atau sikap dan perasaan-perasaan apa yang ingin disampaikan oleh orang tersebut. (3) Ada Tujuan. Setiap interaksi sosial memiliki tujuan tertentu seperti mempengaruhi individu lain. Tujuan yang ingin dicapai bisa secara individu dan kelompok. Untuk mencapai tujuan itu diperlukan adanya struktur dan fungsi sosial.

\section{Gaya Hidup}

Menurut Hall dan Linze (1993), gaya hidup adalah prinsip sistem dengan mana kepribadian individual berfungsi, keseluruhan yang memerintah bagianbagiannya. Gaya hidup merupakan prinsip yang menjelaskan keunikan seseorang. Setiap orang mempunyai gaya hidup tetapi tidak mungkin ada dua orang mengembangkan gaya hidup yang sama.
Menurut Naisbit dan Aburdene (2004), mengatakan bahwa era globalisasi memungkinkan timbulnya gaya hidup global. Orang cenderung mengejar kesempatan untuk bisa memuaskan kebutuhan aktualisasi diri, sekaligus tampil sebagai pemenang dalam persaingan untuk memperoleh yang terbaik, tertinggi dan terbanyak.

Menurut Engel F.J dan Blacwell (1994), mengatakan bahwa gaya hidup adalah perilaku membeli dan memanfaatkan waktu luang. Hal ini berkaitan dengan faktor ekonomi dan demografi seseorang. Menurut Kelly (1990), yaitu teori konstruk dimana setiap manusia akan berusaha mensistimatisir reaksi-reaksinya agar ia dapat mengendalikan sekaligus memprediksikan diri sendiri maupun lingkungannya. Bila ia tidak dapat menciptakan suatu pola perilaku tertentu maka ia akan menghadapi ancaman inkompobilitas dan inkonsintesis 
yang menyebabkan reaksi-reaksinya tidak efektif atau tidak menguntungkan.

Menurut Sajogya (2002), gaya

hidup diartikan secara luas sebagai mode kehidupan yang di identifikasikan dengan bagaimana orang menampilkan kepribadian melalui perilaku sebagai aktualisasi diri terhadap lingkungan yang ada di sekitarnya.

Menurut Poernomo (2004), gaya hidup yang menyangkut pilihan pekerjaan dan makanan. Mode pakaian dan kesenangan telah mengalami perubahan, dengan kepastian mengalirnya pengaruh kota-kota besar terhadap kota-kota kecil, bahkan sampai ke desa. Bentuk-bentuk tradisional, diganti dengan gaya hidup global.

Peneliti menggunakan teori Sugita sebagai acuan untuk membuat alat ukur gaya hidup yaitu: (1) Activity yaitu tingkah laku nyata dapat diobservasi (aktivitas). (2) Interest yaitu tingkah laku yang melatarbelakangi suatu pilihan perilaku. (3)
Opinion yaitu reaksi lisan atau tulisan terhadap pernyataan atau event tertentu.

\section{Konsep Diri}

Gunawan, (2005) menyebutkan bahwa seseorang yang mempunya konsep diri positif akan menjadi individu yang mampu memandang dirinya secara positif, berani mencoba dan mengambil resiko, selalu optimis, percaya diri, dan antusias menetapkan arah dan tujuan hidup.

Craven (2002) menyatakan bahwa konsep diri yang positif akan berhubungan dengan afeksi terhadap diri sendiri (self worth) dan penerimaan diri perasaan terhadap diri sendiri yang positif disertai penerimaan diri, akan membuat perkembangan individu dalam konteks kemasyarakatan, termasuk dalam dunia kerja, menjadi optimal melalui pengenalan tahap-tahap perkembangan dengan pemahaman yang cerdik, pengambilan keputusan yang matang, pengaturan diri 
yang bertanggung jawab dan moral yang otonom (Craven, 2002).

Konsep diri adalah gambaran yang dimiliki seseorang tentang dirinya, yang dibentuk melalui pengalaman-pengalaman yang diperoleh dari interaksi dengan lingkungan (Agustiani, 2009). Teori diri kaca cermin (looking-glass self) menyatakan konsep diri dipengaruhi oleh apa yang diyakini individu bahwa orangorang berpendapat mengenai dirinya. Kaca cermin memantulkan evaluasi-evaluasi yang dibayangkan orang-orang lain tentang individu (Cooley dalam Burns, 1993). Partosuwido, dkk dalam Maria (2007), konsep diri adalah cara bagaimana individu memberi persepsi atau menilai diri sendiri berdasarkan harapan, bagaimana penerimaannya terhadap diri sendiri sebagaimna yang dirasakan, diyakini dan dilakukan, baik ditinjau dari segi fisik, moral, keluarga, personal dan sosial (Berzonsky dalam Maria, 2007) dan (Brooks dalam Rahim, 2009).
Hurlock (dalam Setyani 2007) menyatakan dua aspek konsep diri yaitu aspek fisik dan psikologis. Aspek fisik meliputi konsep mengenai penampilan diri, kesesuaian dengan jenis kelamin, menyadari arti penting tubuh, dan perasaan gengsi di hadapan orang lain yang disebabkan oleh keadaan fisiknya. Aspek psikologis merupakan penilaian seseorang terhadap keadaan psikis dirinya, seperti perasaan mengenai kemampuan atau ketidakmampuannya yang akan berpengaruh terhadap rasa percaya diri pada siswa, dan sebaliknya. Peneliti menggunakan teori Brooks dalam Rakhmat (2002) sebagai acuan untuk membuat alat ukur konsep diri yaitu: (1) Karakteristik konsep diri penampilan fisik, yaitu bagaimana cara seseorang menilai dirinya secara fisik. (2) Karakteristik konsep diri secara psikis, bagaimana cara seseorang menilai dirinya secara psikis. Karakteristik konsep diri secara sosial, 
bagaimana cara seseorang menilai dirinya dalam siatuasi sosial.

\section{METODE}

\section{Subyek Penelitian}

Populasi dalam penelitian ini adalah Siswa SMA Taman Harapan Malang sebanyak 250 tahun ajaran 2014.

Jumlah sampel sebanyak 95 orang kelas 1 (satu), 35 dan kelas 2 (dua), kelas IPS-30 dan IPA-30 dan dalam pemilihan sampel menggunakan teknik simple random sampling, yaitu dengan menggunakan teknik acak sederhana yaitu mengundi daftar hadir dengan cara, setiap nama siswa dicatat di sebuah kertas yang hadir pada saat itu kemudian dimasukkan kedalam kaleng dan diacak. Peneliti kemudian mengambil nama-nama tersebut dari dalam kaleng sesuai dengan jumlah sampel yang telah ditentukan dan dipergunakan untuk mengisi skala atau aitem penelitian yang sudah disediakan oleh peneliti.

\section{Alat Ukur}

Interaksi sosial dalam penelitian ini diukur dengan menggunakan skala interaksi sosial yang berdasar pada percampuran ciri-ciri (Santosa, 2004) dan syarat (Muftuh dan Ruyadi, 1995) yang meliputi aspek kontak sosial, komunikasi dan tujuan. Aitem skala berjumlah 36 butir aitem dengan koefisien validitas butir bergerak dari 0,308 sampai 0,564 dengan reliabilitas Alpha Cronbach sebesar 0,852.

Gaya hidup dalam penelitian ini diukur dengan menggunakan skala Gaya hidup yang berdasar pada pernyataan Sugita (2009) di mana aspek-aspek tersebut antara lain actifity, interest, opinion. Aitem skala berjumlah 36 butir aitem dengan koefisien validitas butir bergerak dari 0,310 sampai 0,585 dengan reliabilitas Alpha Cronbach sebesar 0,805 .

Konsep Diri dalam penelitian ini diukur dengan menggunakan skala Konsep Diri yang berdasar pada teori Brooks (dalam Rakhmat, 2002) yang meliputi aspek 
konsep diri fisik, konsep diri psikis, dan konsep diri sosial. Aitem skala berjumlah 36 butir aitem dengan koefisien validitas butir bergerak dari 0,300 sampai 0,404 dengan reliabilitas Alpha Cronbach sebesar 0,707 .

\section{HASIL PENELITIAN}

Hasil komputasi ANAREG diperoleh

F hitung sebesar 17, 695 dengan db 2:92 diperoleh tabel $\mathrm{F}=4,84(1 \%)$, sehingga $\mathrm{F}$ hitung 17, $695>$ Tabel $F$ dengan nilai $p$ sebesar $0,00 \quad(p<0,01)$. Temuan ini menunjukkan ada korelasi signifikan bersama-sama antara gaya hidup dan konsep diri dengan interaksi sosial. Dengan demikian, hipotesis mayor yang berbunyi “ada korelasi antara gaya hidup dan konsep diri dengan interaksi sosial" dapat diterima.

Hipotesis korelasi ditemukan hasil $F_{\text {reg }}$ di peroleh $F$ hitung sebesar 1, 630 dengan $\mathrm{db}$ 1: 93 diperoleh $\mathrm{F}$ tabel $1 \%=6$, 92, sehingga $\mathrm{F}$ hitung $1,630<\mathrm{F}$ tabel $1 \%$ $(6,92)$ atau $\mathrm{p}<0,205$. Temuan ini menunjukkan tidak ada korelasi yang signifikan antara gaya hidup dengan interaksi sosial. Dengan demikian, hipotesis minor yang berbunyi " tidak ada korelasi antara gaya hidup dengan interaksi sosial" tidak dapat diterima.

Hipotesis korelasi ditemukan hasil $F_{\text {reg }}$ di peroleh $F$ hitung sebesar 31,110 dengan $\mathrm{db}$ 1: 93 diperoleh $\mathrm{F}$ tabel $1 \%=6$, 92 sehingga $\mathrm{F}$ hitung $31,110>\mathrm{F}$ tabel $1 \%$ $(6,92)$ atau $\mathrm{p}<0$, 000. Temuan ini menunjukkan ada korelasi yang signifikan antara konsep diri dengan interaksi sosial. Dengan demikian, hipotesis minor yang berbunyi "ada korelasi antara konsep diri dengan interaksi sosial" dapat diterima.

Hasil koefisien determinan $\left(\mathrm{R}^{2}\right)$ diperoleh hasil sebesar 0,278 yang berarti sumbangan efektif yang diberikan oleh gaya hidup dan konsep diri sebesar 27, $8 \%$, sehingga sumbangan efektif yang tersisa sebesar $72,2 \%$ yang mana dipengaruhi oleh faktor lain. 
Perhitungan sumbangan efektif Terdapat hubungan yang positif antara menunjukkan bahwa gaya hidup gaya hidup dan konsep diri dengan memberikan sumbangan sebesar $0,17 \%$, interaksi sosial, dimana semakin tinggi sedangkan konsep diri sebesar 0,251 . Hal atau positif gaya hidup dan konsep diri ini menunjukkan bahwa dalam maka akan semakin tinggi atau positif menumbuhkan interaksi sosial, konsep diri interaksi sosial yang dialami. Demikian lebih memberikan sumbangan efektif pula sebaliknya semakin rendah atau daripada gaya hidup terhadap interaksi sosial.

\section{PEMBAHASAN}

Hasil penelitian yang telah diuji menunjukkan bahwa hipotesis pertama dari gaya hidup dan konsep diri memiliki korelasi terhadap interaksi sosial dengan koefisien determinan $\mathrm{R}^{2}$ diperoleh hasil 0 , 278 yang berarti sumbangan yang diberikan oleh gaya hidup dan konsep diri terhadap interaksi sosial sebesar 27, $8 \%$ sehingga sisanya sebesar $\quad 72, \quad 2 \%$ dipengaruhi oleh faktor lain. Berarti dalam meningkatkan interaksi sosial yang lebih baik, konsep diri lebih memberikan sumbangan dibandingkan gaya hidup. negatif gaya hidup dan konsep diri maka akan semakin rendah atau negatif interaksi sosial yang dialami.

$$
\text { Hasil penelitian telah }
$$

menggambarkan bahwa terdapat unsur pengaruh mempengaruhi atau terdapat korelasi antara gaya hidup dan konsep diri dengan interaksi sosial. Gaya hidup memberikan sumbangan yang sangat sedikit, yang berarti siswa masih memiliki gaya hidup yang terlihat lewat gadjed mewah yang dapat digunakan untuk membantu mereka dalam membentuk konsep diri positif sehingga munculnya rasa percaya diri dalam mengembangkan interaksi sosial baik di dalam lingkungan sekolah maupun lingkungan masyarakat. 
Hipotesis kedua, menunjukkan bahwa gaya hidup memberikan sumbangan sebesar 0, $17 \%$, yang berarti tidak signifikan atau hipotesis ditolak antara gaya hidup dengan interaksi sosial.

Hal ini dapat terjadi karena menurut peneliti terdapat ketidakseimbangan dalam proses pengambilan data yaitu pengambilan data try out di SMA UNTAG Surabaya dengan cara peneliti terjun langsung menjelaskan dan mengambil data dengan situasi sekolah yang mendukung yaitu pada pagi hari jam 8 yaitu kondisi siswa-i masih segar untuk mengisi skala serta pengambilan data penelitian di SMA Taman Harapan Malang, peneliti tidak terjun langsung tetapi hanya menitipkan angket/ skala terhadap pihak sekolah untuk ditinjaklanjuti. Pihak sekolah tidak menjelaskan maksut dari angket atau skala yang diberikan tetapi langsung diberikan kepada para siswa untuk mengisinya. Hal ini tentu saja sangat berpengaruh terhadap ketidaksignifikan dari variabel gaya hidup terhadap interaksi sosial remaja. Sedangkan tabel blue print dari variabel gaya hidup yang berdasar pada teori Sugita (2009), dengan indikator yaitu takut dikucilkan dan bukan dikatakan gaul serta ketinggalan jaman dari aspek interest hanya memberikan poin 2, yang sangat kecil.

Hasil di atas menggambarkan bahwa siswa di SMA Taman Harapan Malang kurang memiliki gaya hidup yang seharusnya dapat membantu mereka untuk memiliki banyak teman tidak terealisasi dikarenakan indikator-indikator yang menjadi tolak ukur belum diwujutkan sepenuhnya dalam aktifitas hidup seharihari. Namun, tidak dapat dipungkiri bahwa mereka sadar dan masih mengikuti perkembangan zaman saat ini yang terlihat lewat penampilan yang sesuai mode atau tren, kemampuan menyesuaikan diri dengan kelompok sosalita, mampu membeli gadjed bermerek, dan memiki kemampuan untuk menjadi pusat perhatian 
dari lingkungan sekolah serta lingkungan masyarakat. Siswa masih mendatangi pusat-pusat perbelanjaan untuk membeli gadjed mewah dan shoping berbagai merek pakaian sebagai bagian dari tuntutan kebutuhan untuk membantu mengembangkan hubungan pertemanan dalam interaksi sosial.

Hipotesis ketiga, menunjukkan bahwa konsep diri memberikan sumbangan sebesar 0, $251 \%$, yang berarti terdapat signifikansi atau hipotesis diterima antara konsep diri dengan interaksi sosial yang berdasar pada teori Brooks dalam Rakhmat (2002) dengan aspek-aspeknya yang digunakan sebagai acuan pengukuran oleh peneliti lewat uji program komputer program SPSS-21. Hal ini dapat terjadi karena menurut peneliti terdapat keseimbangan dalam proses pengambilan data try out di SMA UNTAG Surabaya dan pengambilan data penelitian di SMA Taman Harapan Malang, dapat disimpulkan bahwa siswa-telah memiliki konsep diri positif dalam mengembangkan interaksi sosial dengan orang lain. Hal ini tentu saja sangat berpengaruh terhadap tingkat signifikan dari variabel konsep diri terhadap interaksi sosial remaja. Sedangkan berdasar pada blue print dari variabel konsep diri, aspek psikis dan sosial sama-sama menghasilkan poin 8, sehingga terdapat keseimbangan dalam meningkatkan interaksi sosial baik. Angka 8 cukup besar untuk menjelaskan bahwa siswa memiliki konsep diri yang positif dalam mengembangkan interaksi sosial dengan orang lain yang terlihat dalam aktivitas hidup sehari-hari baik di sekolah maupun di lingkungan masyarakat.

Hasil di atas menggambarkan bahwa siswa di SMA Taman Harapan Malang telah memiliki konsep diri positif yang dirasa sangat penting untuk membantu mereka dalam berelasi dengan semua orang. Kesadaran akan pentingya konsep diri positif dapat terlihat lewat indikator-indikator yang menjadi tolak 
ukur yang diwujutkan sepenuhnya dalam aktifitas hidup sehari-hari yaitu siswa-i mampu menilai dirinya secara firik, mampu menilai diri secara psikis, dan mampu menilai dirinya dalam situasi sosial. Unsur-unsur tersebut mampu membentuk rasa percaya diri siswa dalam memproses dan melakukan aktifitas sosial dalam lingkungan sekolah dan lingkungan masyarakat, sehingga interaksi sosial yang baik pula dapat berkembang sesuai dengan kebutuhan masing-masing orang. Jadi, peneliti merasa bahwa dengan konsep diri yang selalu positif juga dapat membantu membentuk keribadian siswa yang terarah, sehingga mampu menyesuaikan serta menempatkan diri dalam situasi apapun, kapan dan dimanapun mereka berada.

\section{KESIMPULAN}

Berdasarkan hasil analisis data yang telah dilakukan, diperoleh hasil bahwa ada hubungan yang positif antara gaya hidup dan konsep diri dengan interaksi sosial di
SMA Taman Harapan Malang, dimana semakin tinggi atau positif gaya hidup dan konsep diri maka akan semakin tinggi atau positif interaksi sosial yang dialami. Demikian pula sebaliknya semakin rendah atau negatif gaya hidup dan konsep diri maka akan semakin rendah atau negatif interaksi sosial yang dialami. Hasil perhitungan menunjukkan bahwa sumbangan eefektivitas gaya hidup dan konsep diri dengan interaksi sosial sebesar $27,8 \%$ dan sisanya sebesar $72,2 \%$ dipengaruhi oleh faktor lain yaitu faktor internal dan eksternal.

Berdasarkan hasil pembahasan dari penelitian ini, maka saran yang dapat peneliti ajukan adalah sebagai berikut :

Bagi Remaja

- Remaja mampu mengembangkan gaya hidup positif sesuai perkembangan saman dan konsep diri positif yaitu menumbuhkan rasa percaya diri lewat penampilan fisik seperti sopan, berpikir 
positif dan komunikasi baik dalam interaksi sosial dengan semua orang.

Bagi Peneliti Selanjutnya

- Mengumpulkan informasi sebanyak mungkin mengenai lembaga yang dapat dipakai untuk melakukan penelitian.

- Membuat instrument penelitian dengan menambah faktor-faktor yang berhubungan interaksi sosial.

\section{DAFTAR PUSTAKA}

Ahmadi, A. (1999). Interaksi Sosial. Psikologi Sosial. Penerbit Rineka. Jakarta.

Adam, J.F, (1980). Understanding Adolescence: Currenct-Development in Adolescence Psycology, Fourth Edition, Massachssets.

Ali, M dan Asrori, M. (2004). Konsep Diri. Psikologi Remaja. Jakarta : Bumi Aksara.

Anoraga, Panji dan Suyati. (1995). Interaksi Sosial. Psikologi Industri dan Sosial. Jakarta : Dunia Pustaka Jaya. Gunawan, A.H. (2000). Interaksi dalam Masyarakat. Sosiologi Pendidikan, Rineka Cipta, Jakarta.
Saifuddin, A. (2000). Alat Ukur Penelitian. Sikap Manusia dan Pengukurannya. Yogyakarta : Pustaka Belajar.

Saifuddin, A. (2003). Alat Ukur Psikologi. Tray Out Skala. Yogyakarta : Pustaka Belajar.

Caplin J.P. (1991). Dictionary of Psycology. New York: Dell Pulishing Co.

Rusmawati, Widodo. (2004). Diskrepansi Konsep Diri Ideal dan Kreaativitas pada Remaja. Jurnal Psikologi. UNDIP. Vol Satu, No. Satu, hal 59.

Gerungan. (1996). Interaksi Sosial. Psikologi Sosial. Jakarta: Eresco.

Gim. (2011). Interaksi antar Etnis dalam Masyarakat. Asian Journal of Social Psychology. Volume 14 Issue Satu.

Hadi, S. (2000). Alat Ukur Psikologi. Metodologi Research. Yogyakarta : Andi Offset.

Hadi, S (2001). Analisa Regresi. http//www. Google.com. Diakses tanggal 12 Februari (2011).

Miraningsih, W. (2013). Interaksi Sosial dan Konsep Diri. Jurnal Universitas Negeri Semarang, April.

Muftu, B., Yadi, R. (1995). Hubungan Masyarakat. Sosiologi I. Bandung: Ganesa Exacta. 
Nirwana. (2013). Interaksi Sosial dan Gaya Hidup. Persona, Jurnal Psikologi Indonesia. Vol Dua, No. Dua, hal 154.

Nitisastro Widjoyo. (2000). Modernisasi. http//www. Google.com. Diakses tanggal 15 Februari (2011).

Nugraheni. (2003). Gaya hidup. http//www. Google.com. Tanggal 12 Februari (2011).

Pratikto Herlan. (2012). Hubungan antara Konsep Diri dengan Kompetensi Interpersonal Mahasiswa, Kematangan Emosi, Konsep Diri dan Kenakalan Remaja. Persona, Jurnal Psikologi Indonesia. Vol Dua, No. Satu, hal Delapan.

Press Diva Piliang, Y.A. (2005). Hubungan

Sosial dalam Masyarakat. Ekspresi Cinta, Seks, dan Jati Diri. Yogyakarta. Ramdhani Neila. (1996). Perubahan Perilaku dan Konsep Diri Remaja yang Sulit Bergaul Setelah Menjalani Pelatihan Ketrampilan Sosial. Jurnal Psikologi. Universitas Gadjah Mada Yogyakarta. No. 1, hal 13.

Revida Erika. (2006). Interaksi Sosial.

Jurnal Harmoni Sosial, September. Volume Satu, No. Satu.

Sarwono, Wirawan, Sarlito. (1992).

Remaja dan Keluarga. Psikologi Sosial. Jakarta: BPK Gunung Mulia.
Soejatmoko. (2003). Modernisasi. http//www. Google.com. Diakses tanggal 15 Februari (2011).

Soekamto, Sarjono. (2006). Interaksi. Sosiologi Suatu Pengantar. Jakarta: PT Raja Grafindo Persada.

Sudjiwanati. (2008). Gaya hidup, konsep diri, dan self esteem. Jurnal Psikovidya. Vol. 12. No. Dua.

Sugita. (2009). Gaya Hidup Modern. http//www. Google.com. Diakses tanggal 20 Februari (2011).

Suparno. (2013). Gaya Hidup. Interaksi Sosial dengan Teman Sebaya pada Anak Homeschooling dan Anak Sekolah Reguler. Persona Jurnal Psikologi Indonesia. Vol Dua, No. Satu, hal 41-42.

Suparno, Eka Setiawati. (2010). Gaya Hidup dan Konsep Diri. Indigenus Jurnal Ilmiah Berkala Psikologi d.h. Kognisi. Vol. 12, No. 1, hal 55.

Suryawati, Maryati. (2013). Interaksi Sosial. Jurnal PPKN UNJ Online. Vol Satu, No. Dua, ISSN:2337-5205).

Susianto. (1999). Deskriptif Gaya Hidup Sebagai Kebutuhan Psikologi. www.Google.com. Diakses pada tanggal 30 April (2008).

Swa Sembada. (1995). Gaya hidup berkomunikasi. 
http//www.Google.com. Diakses Under Filed. (2010). Gaya hidup tanggal 30 April (2010). http//www. Google.com. Diakses

Syaifudin Anwar. (1995). Gaya Hidup tanggal 20 Februari (2011).

Modern. http//www. Google.com.

Walgito, Bimo. (2003). Interaksi Sosial.

Diakses tanggal 20 Februari (2011).

Pratitis dan Agustinus. (2013). Harga Diri Psikologi Sosial: Suatu Pengantar. Yogyakarta: Andi Offset dan Interaksi Sosial Ditinjau dari Status Sosial Ekonomi Orang Tua dengan Subyek. Persona, Jurnal Widiastutik, Y. (1999). Deskriptif Tentang Gaya Hidup Sebagai Kebutuhan Psikologi. Psikovidya.

Psikologi Indonesia. Vol Dua, No. 131. 